\title{
Clover nutrient ratios to monitor pasture yield responses to fertiliser nutrients
}

\author{
J.D. MORTON, L.C. SMITH and J.D. MORRISON
}

AgResearch, Invermay Agricultural Centre, PB 50034, Mosgiel

\section{Abstract}

From earlier results of a limited number of trials, ratios of concentrations of phosphorus $(\mathrm{P})$, sulphur $(\mathrm{S})$ and potassium $(\mathrm{K})$ to nitrogen $(\mathrm{N})$ in white clover have been developed as indicators of nutrient adequacy. For $98 \%$ of maximum yield, clover herbage ratios of $7.4(100 \times \mathrm{P} / \mathrm{N}), 5.0(100 \times \mathrm{S} / \mathrm{N})$ and $0.43(\mathrm{~K} / \mathrm{N})$ were required. Mean critical nutrient concentrations have been reported as $0.35 \% \mathrm{P}$, $0.28 \% \mathrm{~S}$ and $2.05 \% \mathrm{~K}$ from earlier research on sites at an early stage of pasture development. A series of mowing trials, measuring pasture yield responses to nil or a high rate of $\mathrm{P}(120 \mathrm{~kg} / \mathrm{ha}), \mathrm{S}(100 \mathrm{~kg} / \mathrm{ha})$ and $\mathrm{K}(300 \mathrm{~kg} / \mathrm{ha})$ were carried out at 8 sites throughout New Zealand in 1997/98. There were significant $(\mathrm{P}<0.05)$ clover or total pasture dry matter (DM) yield responses to $\mathrm{P}$ at 7 sites, $\mathrm{S}$ at one site, and $\mathrm{K}$ at 6 sites. The results indicated that the optimum clover nutrient ratios reported from earlier research are valid over a wide range of environments. Clover $\mathrm{P} / \mathrm{N}$ and $\% \mathrm{P}$, and $\mathrm{K} / \mathrm{N}$ and $\%$ $\mathrm{K}$ accurately assessed the effectiveness of $\mathrm{P}$ and $\mathrm{K}$ applications and were reliable indicators of a pasture yield response. Clover $\mathrm{S} / \mathrm{N}$ and $\% \mathrm{~S}$ were equally accurate measures of the correction of a S deficiency at the one S-responsive site, but neither measure increased after $\mathrm{S}$ application at other nonresponsive sites. Clover $\mathrm{S} / \mathrm{N}$ was more accurate than $\% \mathrm{~S}$ for indicating a DM response to $\mathrm{S}$. A lower mean critical concentration of $0.24 \% \mathrm{~S}$ in clover would have been more appropriate for these well developed sites.

Keywords: nitrogen, nutrient concentrations, nutrient ratios, phosphorus, potassium, sulphur, white clover

\section{Introduction}

In New Zealand, fertiliser nutrients (phosphorus (P), sulphur (S) and potassium (K)) are applied primarily for white clover growth and nitrogen $(\mathrm{N})$ fixation. Since fertiliser makes up a significant proportion of operating costs on New Zealand farms, and deficits or excesses of nutrient can damage the environment, it is important that correct amounts of fertiliser nutrients are applied. Whereas soil testing estimates the amount of plantavailable $\mathrm{P}, \mathrm{S}$ and $\mathrm{K}$ present in soil, pasture analysis is required to measure plant uptake of these nutrients. Single nutrient concentrations have been used for this, but interpretation can be limited by the large seasonal variability in relation to critical levels (Roberts 1987). Nutrient ratios in clover may more accurately assess the effectiveness of fertiliser applications and can also be used to indicate whether there will be a pasture yield response to an applied nutrient.

Research has been carried out at two sites in Southland (Sinclair et al. 1997; Morton et al. 1998) to determine nutrient ratios in clover for balanced and adequate nutrition. Balanced nutrition occurs when there is sufficient supply of one nutrient so as not to limit the pasture yield response to another nutrient. Using $\mathrm{N}$ concentration as an internal standard in clovers which fix only enough $\mathrm{N}$ for their own requirements, adequate nutrition occurs when the ratio of $\mathrm{P}, \mathrm{S}$ and $\mathrm{K}$ to $\mathrm{N}$ is at the required level to achieve a specific relative pasture yield (RY) with balanced nutrition. Clover $100 \times \mathrm{P} / \mathrm{N}$ and $100 \times \mathrm{S} / \mathrm{N}$ ratios have been measured as 7.4 and 5.0 respectively for $98 \%$ of maximum clover yield (Sinclair et al. 1997). The K/N ratio in clover for high RY has not been as well defined, but a best estimate from the literature was 0.43 for high RY. The only reported mean critical levels for nutrient concentrations in clover, defined as minimum concentrations of nutrients in plant tissues for maximum yields (McNaught 1970), were $0.35 \% \mathrm{P}, 0.28 \% \mathrm{~S}$, and $2.05 \%$ $\mathrm{K}$. These critical levels were measured on sites at an early stage of pasture development and may differ on more developed sites. Morton et al. (1998) reported a higher clover \% S (0.27\%) and $100 \times \mathrm{S} / \mathrm{N}(5.64)$ for $95 \%$ RY on a site with low fertility compared with values of $0.23 \% \mathrm{~S}$ and $4.8(100 \times \mathrm{S} / \mathrm{N})$ measured by Sinclair et al. (1997) on a higher-fertility site. The higher clover $\% \mathrm{~S}$ and $\mathrm{S} / \mathrm{N}$ ratio required for high $\mathrm{RY}$ on the less developed site was attributed to more reliance on $\mathrm{N}$ fixation rather than soil mineral $\mathrm{N}$, thus requiring a greater supply of $\mathrm{S}$.

The objective of this research was to (a) verify the optimal clover nutrient ratios and nutrient concen- 
trations, and (b) assess their ability to determine that a nutrient deficiency has been corrected by application of fertiliser, and indicate dry matter (DM) yield responses to applied nutrients. This paper reports on nutrient response trials carried out under mowing at eight sites with low soil available levels of one or more of $\mathrm{P}, \mathrm{S}$ or K, throughout New Zealand in 1997/98.

\section{Materials and methods}

Sites with low soil available P, S or K (or combinations of) were selected so that pasture yield responses would quickly occur (Table 1 ). Trial design was $2 \times 2 \times 2$ factorial with 3 replicates. Treatments were with and without $P$ ( 0 and $120 \mathrm{~kg} / \mathrm{ha}$ as mono-calcium phosphate), S (0 and $120 \mathrm{~kg} / \mathrm{ha}$ as gypsum), and $\mathrm{K}(0$ and $300 \mathrm{~kg} / \mathrm{ha}$ as potassium chloride). High rates of nutrients were chosen to ensure that the nutrient deficiency was corrected and maximum yield responses were obtained. $\mathrm{P}$ was applied at the start of the trial in August 1997, S at equal rates at the start and in February 1998, and $\mathrm{K}$ at equal rates at the start, November 1997, and February 1998. Basal applications of $200 \mathrm{~g} / \mathrm{ha}$ sodium molybdate, $30 \mathrm{~kg} / \mathrm{ha}$ magnesium oxide, and $11.25 \mathrm{~kg} / \mathrm{ha}$ sodium borate were applied at the start of the trial. Each site was cut every 4-6 weeks from August 1997 to April 1998, except Waipawa where pasture growth ceased in November, 1997 owing to drought, and Taieri, where pasture yield was measured only from January to March 1998 because of slow establishment of oversown clover. At each cut, two strips were mown from each $6 \mathrm{~m}^{2}$ plot to measure DM production. Clippings were discarded to increase the likelihood of DM responses. For the October/ November and February/March cuts, pasture samples were collected from the centre of each plot. White clover

Table 1 Location of trial sites, soil type and group, and initial soil nutrient status.

\begin{tabular}{llccccc}
\hline Site & Soil type and group & $\begin{array}{c}\text { Olsen P } \\
(\mu \mathrm{g} / \mathrm{ml})\end{array}$ & $\begin{array}{c}\text { Sulph-S } \\
(\mu \mathrm{g} / \mathrm{g})\end{array}$ & $\begin{array}{c}\text { Org-S } \\
(\mu \mathrm{g} / \mathrm{g})\end{array}$ & $\begin{array}{c}\text { Quick } \\
\text { test K }\end{array}$ & $\begin{array}{c}\text { TBK } \\
(\mathrm{cmol} / \mathrm{kg})\end{array}$ \\
\hline Whangarei & Mangakahia YBE & 10 & 7 & 6 & 5 & 2.61 \\
Rotorua & Ngakuru YBP & 14 & 17 & 10 & 3 & 0.34 \\
Hawera & Egmont YBL & 6 & 22 & 15 & 5 & 0.43 \\
Waipawa & Matapiro YGE & 6 & 5 & 7 & 5 & 0.47 \\
Winchmore & Lismore YGE/YBE & 10 & 6 & 4 & 7 & 1.72 \\
Taieri & Otokia YGE & 4 & 4 & 5 & 4 & 0.55 \\
Gore & Mataura recent & 21 & 5 & 3 & 3 & 2.51 \\
Woodlands & Waikiwi YBE & 13 & 5 & 11 & 4 & 0.66 \\
\hline
\end{tabular}

was separated from these samples and analysed for $\mathrm{N}$, $\mathrm{P}, \mathrm{S}$ and $\mathrm{K}$.

Using the NZ Soil Classification (Hewitt 1998), the yellow-brown earths are classed as firm brown soils, the yellow-brown pumice as an orthic pumice soil, the yellow brown loam as an orthic allophanic soil, the yellow-grey earths as argillic pallic (Matapiro) and fragic pallic (Otokia) soils, and the YGE/YBE as a stony brown soil.

\section{Results}

\section{Clover and total DM production (Figure 1)}

There were significant responses in clover $\mathrm{DM}(\mathrm{P}<0.05)$ to $\mathrm{P}$ at Rotorua, Hawera, and Winchmore, and in total DM at these sites plus Waipawa, Taieri and Woodlands (Figure 1A). The only site where there was a significant clover and total DM response to $\mathrm{S}$ was Winchmore (Figure 1B). Total and clover DM responses $(\mathrm{P}<0.05)$ to $\mathrm{K}$ occurred at Rotorua, Hawera, Winchmore, Taieri and Woodlands, with a total DM response only at Waipawa (Figure 1C).

Clover nutrient concentrations and ratios (Figure 2) In the control plots, clover $100 \times \mathrm{P} / \mathrm{N}$ was below the optimum level ( 7.4 for $98 \% \mathrm{RY}$ ) at all sites except Whangarei and Gore (Figure 2A), but clover $100 \times \mathrm{S} / \mathrm{N}$ was below optimum (5.0 for $98 \% \mathrm{RY}$ ) at Waipawa, Winchmore and Taieri (Figure 2B). Clover $\mathrm{K} / \mathrm{N}$ ratios were less than the optimum level at Rotorua, Hawera, Winchmore, Taieri and Woodlands (Figure 2C). The controls plots at all sites except Whangarei and Gore had $\% \mathrm{P}$ below the mean critical concentration $(0.35 \%)$. Clover \% S was below the mean critical concentration $(0.28 \%)$ at all sites. In the control plots, $\% \mathrm{~K}$ was less than optimum $(2.05 \%)$ at all sites except Whangarei, Waipawa and Gore.

$\mathrm{P}$ application significantly increased clover $\mathrm{P} / \mathrm{N}$ and $\% \mathrm{P}(\mathrm{P}<0.05)$ above the optimal levels at all sites (Figure 2A). Although DM responses to $\mathrm{S}$ occurred only at Winchmore, $\mathrm{S}$ application significantly increased clover $\mathrm{S} / \mathrm{N}$ at all sites except Taieri (Figure 2B). Applied S significantly increased clover $\% \mathrm{~S}$ at all sites, but not above the critical level at Hawera, Taieri, and Woodlands. $\mathrm{K}$ application significantly increased clover $\mathrm{K} / \mathrm{N}$ and $\% \mathrm{~K}$ at all sites except Waipawa, and also failed to achieve the optimum levels at Taieri (Figure 2C).

Indication of DM responses (Table 2) At several sites, the clover DM responses were not significant (Figure 1) because of the large variability in clover content between plots. Therefore a significant $(\mathrm{P}<0.05)$ response in either clover or total DM was used as the indication of a DM response to a specific nutrient (Table 2). DM responses to $\mathrm{P}$ were correctly indicated by clover $\mathrm{P} / \mathrm{N}$ and $\% \mathrm{P}$ at six of seven $\mathrm{P}$-responsive sites. Clover $\mathrm{S} / \mathrm{N}$ indicated a DM response to $\mathrm{S}$ at two sites where no response was mea-sured, compared with $\% \mathrm{~S}$ giving an incorrect indication at seven sites. DM responses to $\mathrm{K}$ were correctly indicated by clover $\mathrm{K} / \mathrm{N}$ or $\% \mathrm{~K}$ at five of the six $\mathrm{K}$-responsive sites. 
Figure 1 Effect of $P(A), S(B)$, and $K(C)$ fertiliser on clover and total DM production. Error bars are $\mathrm{LSD}_{0.05}$.

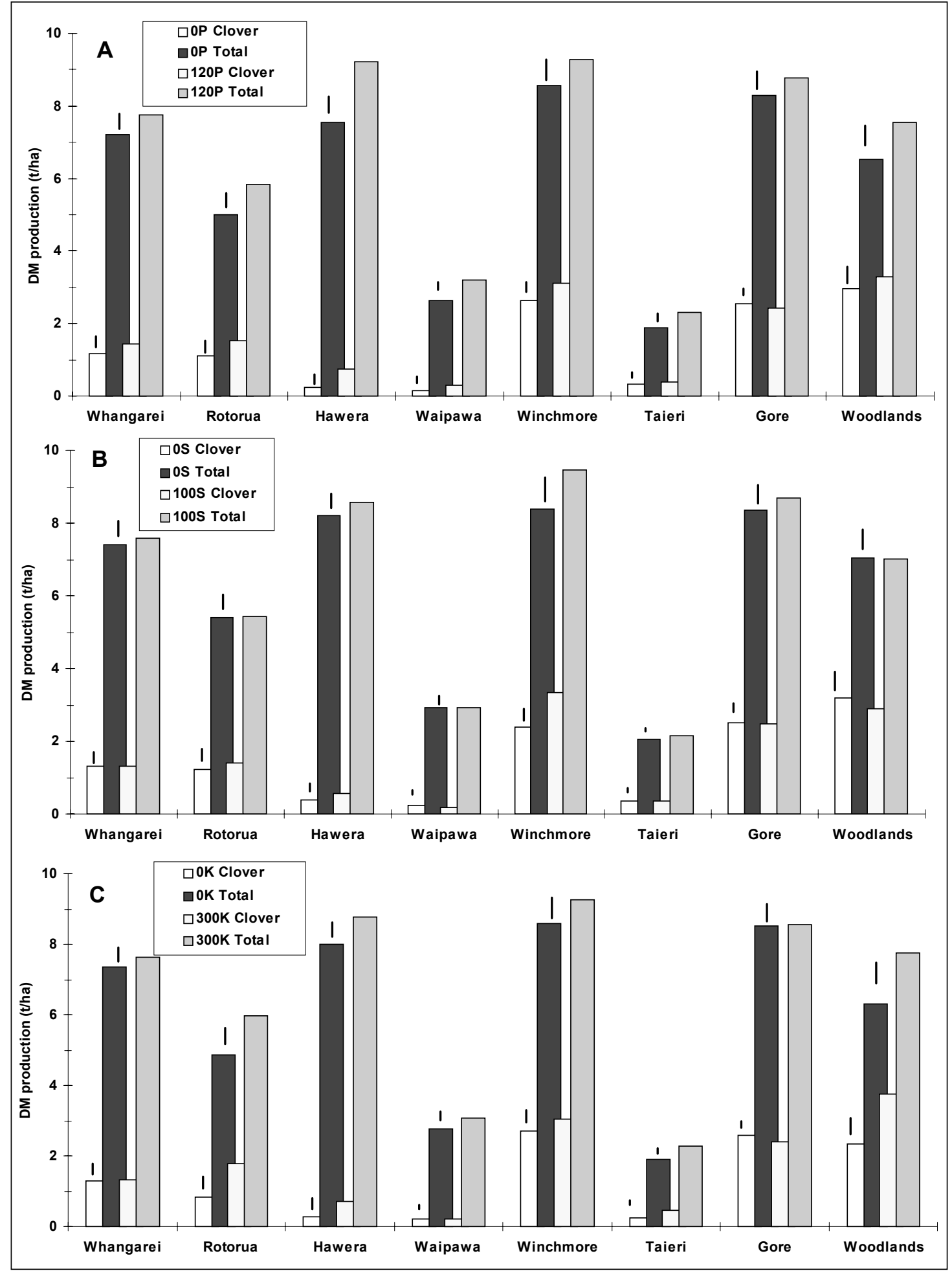


Figure 2 Clover nutrient ratios and concentrations for $P(A), S(B)$, and $K(C)$ for nil (clear) and high (shaded) fertiliser. Horizontal lines are optimal levels and bars are $\mathrm{LSD}_{0.05}$.

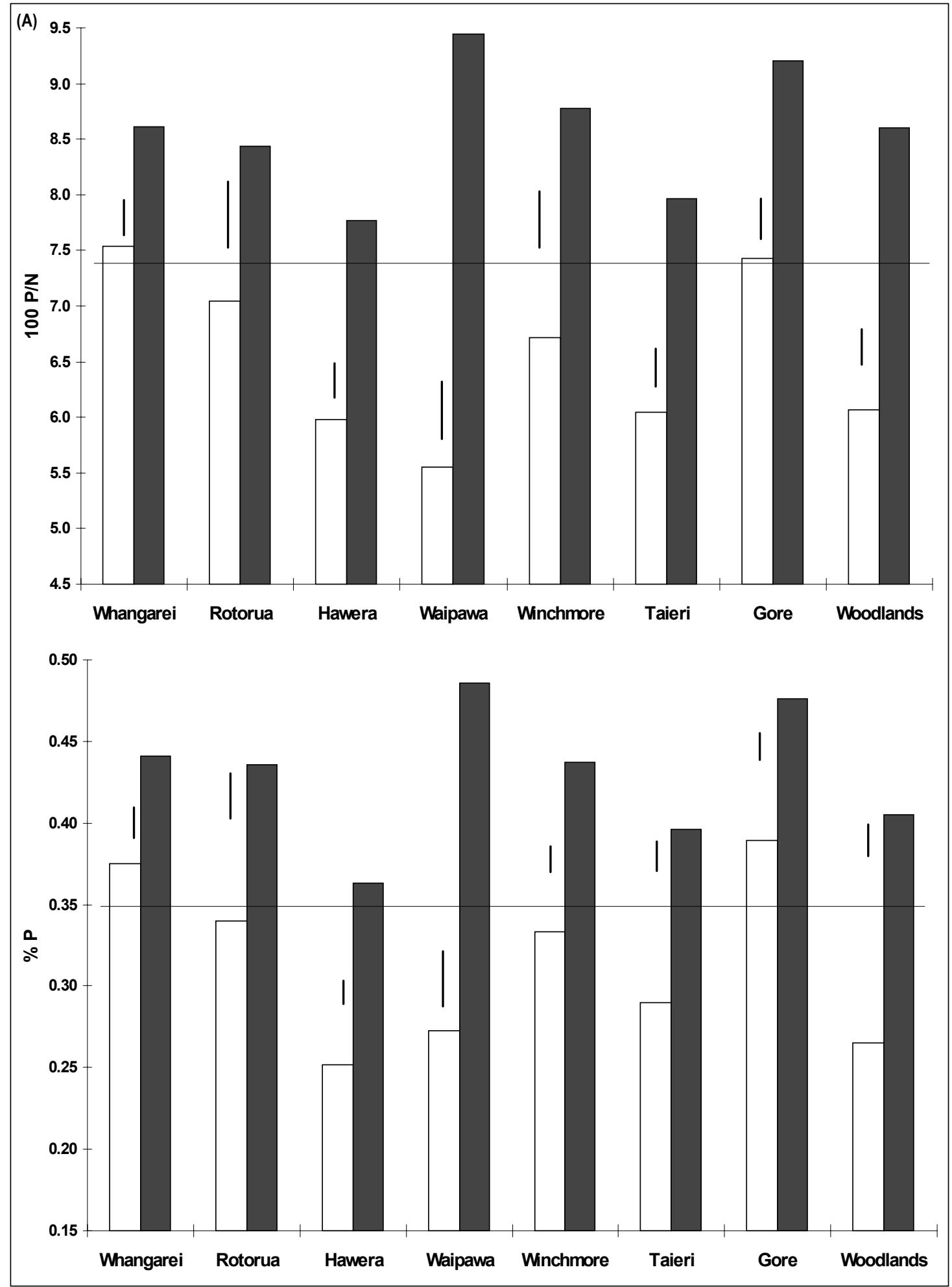




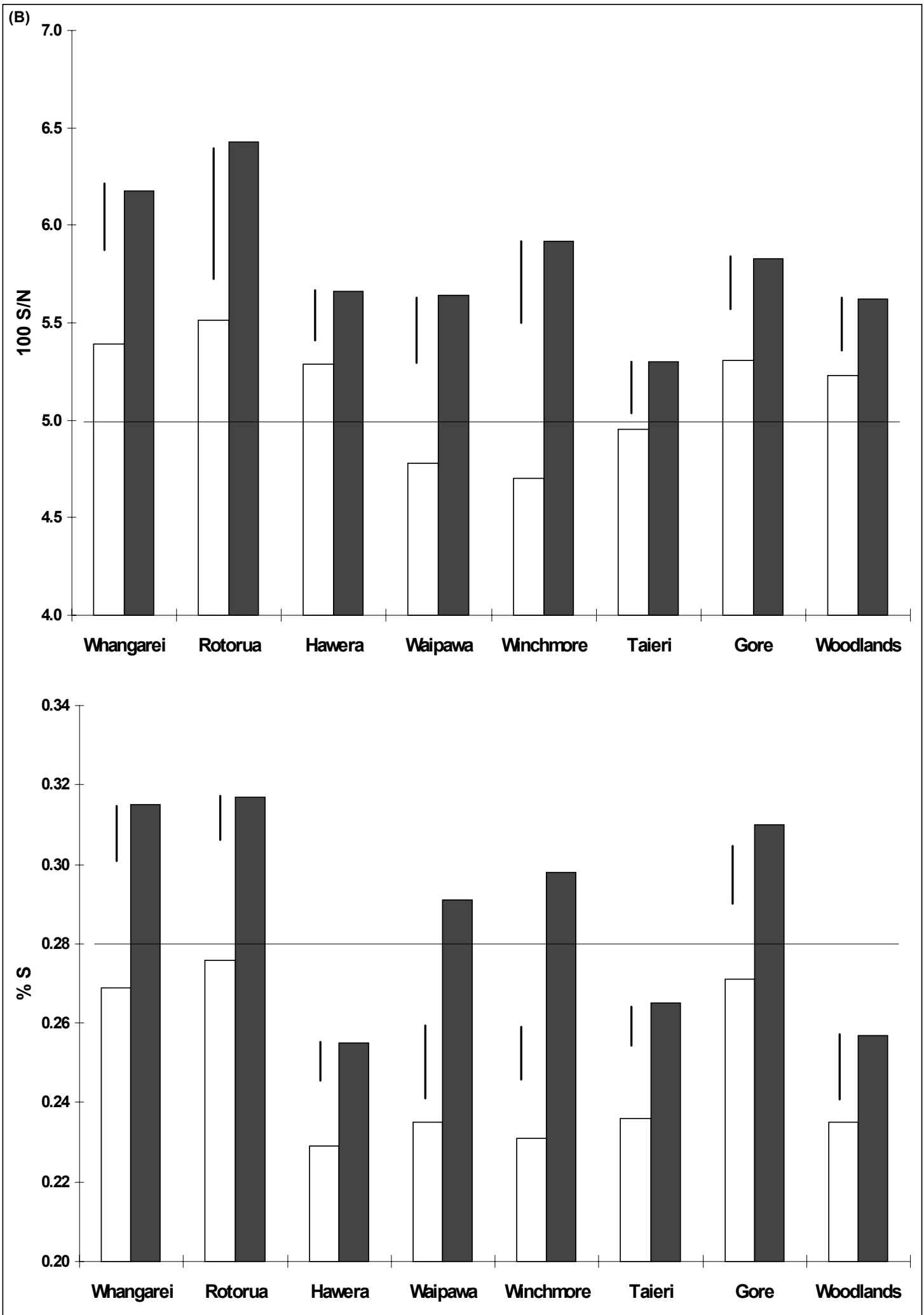




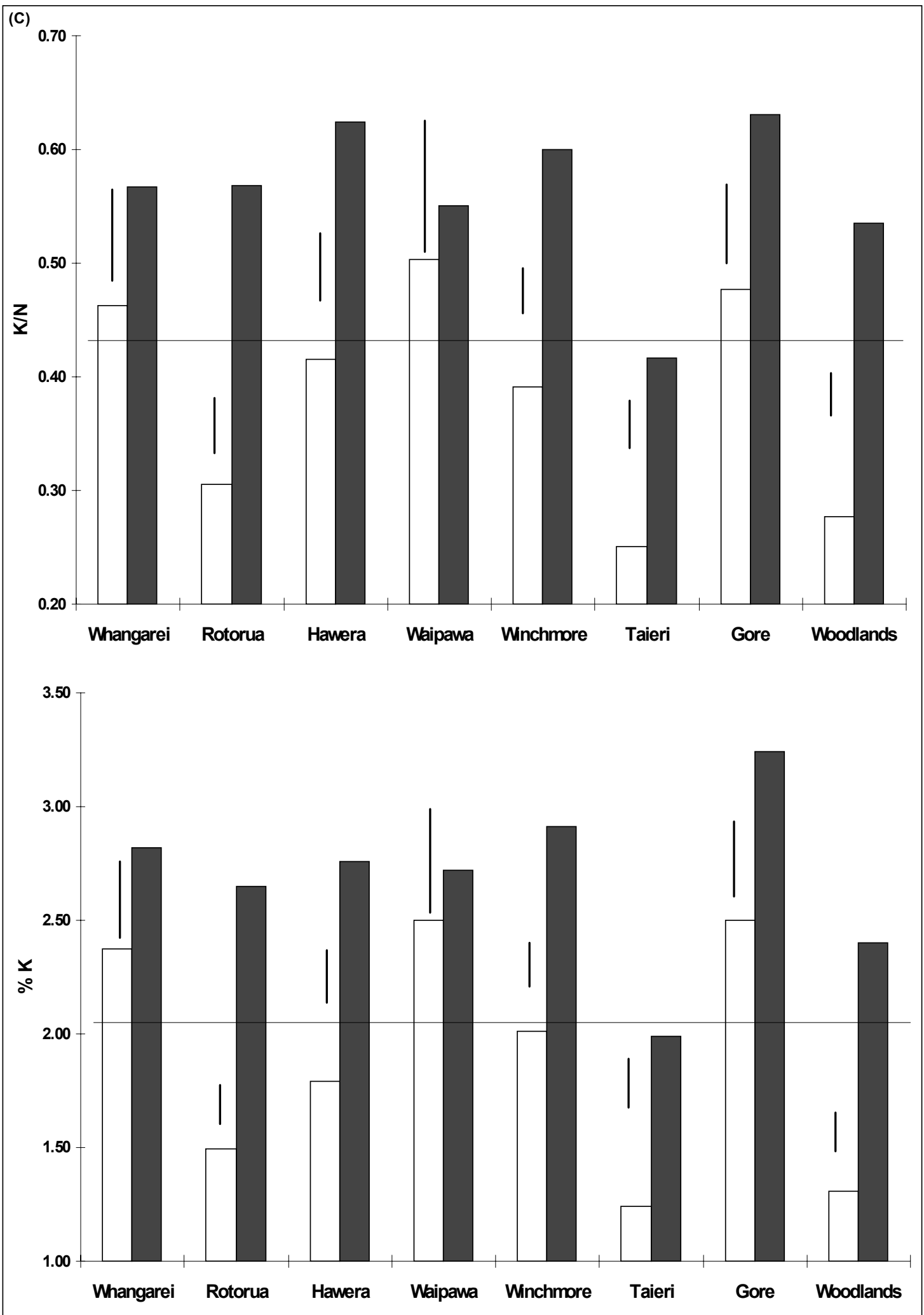


Table 2 Indication of DM responses from clover nutrient ratios and concentrations in the control plots.

\begin{tabular}{|c|c|c|c|c|}
\hline \multirow[b]{2}{*}{ Site } & \multicolumn{2}{|c|}{$\begin{array}{l}\text { DM responses to nutrient } \\
\text { indicated using: }\end{array}$} & \multicolumn{2}{|c|}{$\begin{array}{l}\text { Nutrient with measured } \\
\text { response in: }\end{array}$} \\
\hline & Ratios & Concentrations & Clover DM & Total DM \\
\hline Whangarei & & S & & $P^{*}$ \\
\hline Rotorua & $\mathrm{P}, \mathrm{K}$ & $\mathrm{P}, \mathrm{S}, \mathrm{K}$ & $\mathrm{P}^{*}, \mathrm{~K}^{\star *}$ & $\mathrm{P}^{* *}, \mathrm{~K}^{* *}$ \\
\hline Hawera & $\mathrm{P}, \mathrm{K}$ & $\mathrm{P}, \mathrm{S}, \mathrm{K}$ & $\mathrm{P}^{*}, \mathrm{~K}^{*}$ & $\mathrm{P}^{* *}, \mathrm{~K}^{\star *}$ \\
\hline Waipawa & $P, S$ & $P, S$ & & $\mathrm{P}^{* *}, \mathrm{~K}^{*}$ \\
\hline Winchmore & $\mathrm{P}, \mathrm{S}, \mathrm{K}$ & $\mathrm{P}, \mathrm{S}, \mathrm{K}$ & $\mathrm{P}^{*}, \mathrm{~S}^{* *}$ & $\mathrm{P}^{*}, \mathrm{~S}^{* *}, \mathrm{~K}^{*}$ \\
\hline Taieri & $\mathrm{P}, \mathrm{S}, \mathrm{K}$ & $\mathrm{P}, \mathrm{S}, \mathrm{K}$ & $\mathrm{K}^{*}$ & $\mathrm{P}^{* \star}, \mathrm{K}^{\star *}$ \\
\hline Gore & & $\mathrm{s}$ & & \\
\hline Woodlands & $\mathrm{P}, \mathrm{K}$ & $\mathrm{P}, \mathrm{S}, \mathrm{K}$ & $\mathrm{K}^{\star *}$ & $\mathrm{P}^{\star *}, \mathrm{~K}^{\star \star}$ \\
\hline
\end{tabular}

Levels of significance ${ }^{* *}=P<0.01,{ }^{*}=P<0.05$,

\section{Discussion}

Pasture DM responses to $\mathrm{P}$ were consistent with the lower than optimum initial soil Olsen P levels $(<20 \mu \mathrm{g} /$ $\mathrm{ml})$ measured at 7 of the 8 sites. Although soil Olsen $\mathrm{P}$ generally predicted DM responses to $\mathrm{P}$ at these mainly low-P sites, this does not always occur in practice for the marginal range of $10-20 \mu \mathrm{g} / \mathrm{ml}$. As an alternative, clover $\mathrm{P} / \mathrm{N}$ and $\% \mathrm{P}$ were equally accurate indicators of $\mathrm{DM}$ responses to $\mathrm{P}$ and measures of the correction of a $P$ deficiency.

Pasture DM responses to $\mathrm{S}$ could have been expected at 5 sites where low soil sulphate-S and organic-S $(<10 \mu \mathrm{g} / \mathrm{g})$ were measured but occurred only at one site. Since $\mathrm{S}$ soil tests cannot reliably indicate a DM response to applied $\mathrm{S}$, it is important that a more accurate indicator is available. There has been increased use of S-free fertilisers (e.g., di-ammonium phosphate, triple superphosphate) and users need information on whether $\mathrm{S}$ should be added. Clover $\mathrm{S} / \mathrm{N}$ ratios were a reasonably accurate indicator of the lack of DM response to $\mathrm{S}$ and could be used in this role. The lack of DM response to $\mathrm{S}$ at 7 sites where \% $\mathrm{S}$ was less than $0.28 \%$, suggested that this reported mean critical concentration (McNaught 1970) was too high. A lower critical level of $0.24 \% \mathrm{~S}$ was reported by Sinclair et al. (1997) on a well developed pasture at one Southland site. At another Southland site which was at an earlier stage of pasture development similar to the sites from which McNaught (1970) derived his values, 0.27\% S was required to achieve a high RY (Morton et al. 1998). The reported results further support the use of a critical concentration of $0.24 \% \mathrm{~S}$ for clover in well developed pastures.

Although both low clover $\% \mathrm{~S}$ and $\mathrm{S} / \mathrm{N}$ indicated a $\mathrm{DM}$ response to $\mathrm{S}$ at the S-responsive site, there were insufficient S-responsive sites to fully test the ability of these measures to indicate a DM response to $\mathrm{S}$, or determine whether a $\mathrm{S}$ deficiency has been corrected.
Because $\mathrm{S}$ is a relatively cheap nutrient, it is important that adequate rates are applied to overcome any deficiency. Although clover \% S increased above the mean critical concentration with $\mathrm{S}$ application at the S-responsive site, it did not increase above this level at 3 other nonresponsive sites. This suggested that the optimum level was too high as discussed above, or that the applied S was not taken up by the pasture. Leaching of the applied sulphate-S in gypsum could be largely discounted, since rainfall during $1997 / 98$ at the three sites where this occurred (Hawera, Taieri, and Woodlands) was no higher than the other sites. In addition, mean anion storage capacity $(54 \%)$ at these sites was higher than the average of the other 5 sites $(32 \%)$. The increase in clover $\mathrm{S} / \mathrm{N}$ after $\mathrm{S}$ application at all of the sites was different to earlier results at two Southland sites (Sinclair et al. 1997; Morton et al. 1998), where clover $\mathrm{S} / \mathrm{N}$ did not increase with application of $\mathrm{S}$, because of the stimulatory effect of $\mathrm{S}$ on $\mathrm{N}$ fixation.

Low soil quick test $\mathrm{K}$ ( 5 or less) and TBK $(<1 \mathrm{c} \mathrm{mol} /$ $\mathrm{kg}$ ) values resulted in DM responses to $K$ at 5 sites. One site (Winchmore) had a DM response despite high soil quick test and TBK levels. DM responses to K usually occur at a soil quick test $\mathrm{K}$ of 4-5 or less and TBK of less than $1 \mathrm{c} \mathrm{mol} / \mathrm{kg}$, but at levels just below or above these, DM responses to $\mathrm{K}$ are less easy to predict. Clover $\mathrm{K} / \mathrm{N}$ and $\% \mathrm{~K}$ were equally accurate indicators of a DM response to $\mathrm{K}$ and the correction of a $\mathrm{K}$ deficiency.

The results of these trials show that the mean critical concentrations for $\mathrm{P}$ and $\mathrm{K}$ as reported by McNaught (1970) were better calibrated with pasture DM response than $\mathrm{S}$. The general relationship between DM response to $\mathrm{K}$ and clover $\mathrm{K} / \mathrm{N}$ helped confirm a ratio of 0.43 as the optimum level for high RY. Similarly, the results also support the reported optimal clover $\mathrm{P} / \mathrm{N}$ and $\mathrm{S} / \mathrm{N}$ ratios for high RY.

Overall, the results are further evidence that clover nutrient ratios are useful additional measures to soil tests and clover nutrient concentrations for assessing the ability of nutrient application to correct a deficiency, and indicating yield responses to fertiliser nutrients. In practice, to assess the effectiveness of fertiliser nutrient application, pasture should be sampled at least six weeks after fertiliser application from a minimum of 3 paddocks, once vigorous growth occurs in spring. Clover is then analysed for N, P, K, and S to check that these are in adequate supply. A further measurement from the same paddocks can be made in autumn to assess the effectiveness of corrective applications, or ensure that the nutrients applied in spring were sufficient for the whole growth season. 


\section{Conclusions}

1. The earlier reported clover $\mathrm{P} / \mathrm{N}, \mathrm{S} / \mathrm{N}, \mathrm{K} / \mathrm{N}, \% \mathrm{P}$ and $\% \mathrm{~K}$ for high relative pasture yield were further confirmed over a wide range of sites. There was further evidence that the critical mean concentration of $0.28 \% \mathrm{~S}$ in clover was too high for well developed pastures, and that a value of $0.24 \% \mathrm{~S}$ would be more appropriate.

2. Clover $\mathrm{S} / \mathrm{N}$ and $\% \mathrm{~S}$ consistently increased with fertiliser $\mathrm{S}$ application, but since only one site was $\mathrm{S}$ responsive, more research is needed to evaluate these measures. At the S-responsive site, clover $\mathrm{S} / \mathrm{N}$ was an accurate indicator of DM responses to ap-plied $\mathrm{S}$.

3. Clover $\mathrm{P} / \mathrm{N}$ and $\% \mathrm{P}$, and clover $\mathrm{K} / \mathrm{N}$ and $\% \mathrm{~K}$ were all equally effective, either for assessing the ability of fertiliser application to correct a P or K deficiency, or for indicating a DM response to $\mathrm{P}$ or $\mathrm{K}$.

\section{ACKNOWLEDGEMENTS}

The authors wish to thank Colleen Wheeler, Dennis Enright, Robin Burton, Maurice Gray, Andrew Wards, Rachael Barton, Martin Hawke, and Brian Hunt for their technical assistance, and the farmers on whose land the trials were sited.

\section{REFERENCES}

Hewitt, A.E. 1998. New Zealand Soil Classification. Landcare Research Science Series No 1. Manaaki Whenua Press, Lincoln, Canterbury, New Zealand.

McNaught, K.J. 1970. Diagnosis of mineral deficiencies in grass-legume pastures by plant analysis. Proceedings of the XI International Grassland Congress: 334-338.

Morton, J.D.; Sinclair, A.G.; Morrison, J.D.; Smith, L.C.; Dodds, K.G. 1998. Balanced and adequate nutrition of phosphorus and sulphur in pasture. New Zealand journal of agricultural research 41 : 487-496.

Roberts, A.H.C. 1987. Seasonal variation in soil tests and nutrient content of pasture at two sites in Taranaki. New Zealand journal of experimental agriculture 15: 283-294.

Sinclair, A.G.; Morrison, J.D.; Smith, L.C.; Dodds, K.G. 1997. Determination of optimum nutrient element ratios in plant tissue. Journal of plant nutrition 20(9): 1069-1083. 